\title{
Mengenal Gerakan Sosial dalam Perspektif Ilmu Sosial
}

\author{
Understanding Social Movements from the Perspective of Social Science \\ Andi Haris, Asyraf Bin Hj. AB Rahman', Wan Ibrahim Wan Ahmad ${ }^{3}$ \\ ${ }^{1}$ Dosen Sosiologi Fisip Universitas Hasanuddin, Makassar, Indonesia, email: aharis2000@yahoo.com \\ ${ }^{2}$ Dosen University Malaysia Terengganu, Malaysia \\ ${ }^{3}$ Dosen University Utara Malaysia, Malaysia
}

\section{A R T I C L E I N F O}

\section{How to Cite:}

Haris, A., Rahman, A. B., \&

Ahmad, W. I. (2019).

Mengenal Gerakan Sosial

dalam Persfektif Ilmu Sosial.

Hasanuddin Journal of

Sociology (HJS), 1(1), 15-24.

\section{Keywords:}

Social Movement, organization, social

phenomena, sociological

perpective.

\section{Kata Kunci :}

Gerakan Sosial, organisasi, fenomena social, Perspektif sosiologi.

\begin{abstract}
A B S T R A C T
This article was based on liberary resear that focus on social movement.After observing field research showed that social movement had many kind of fromes such as organization that had same jobs, gender, ethnic, race, religion and social economy status. As a social phenomena , social movement, grows up rapidly that caused by social change.Besides that from sociologycal perspektive that existence of social movement is meant to response certain goals.
\end{abstract}

\section{A B S T R A K}

Tulisan ini merupakan hasil penelitian pustaka yang membahas tentang gerakan sosial. Dari hasil kajian pustaka dan pengamatan dilapangan menunjukkan bahwa gerakan sosial memiliki beragam bentuk mulai dari gerakan yang dilakukan oleh sejumlah orang yang didasarkan pada persamaan latar belakang profesi, gender, suku, ras, agama sampai pada persamaan status sosial ekonomi. Sebagai salah satu fenomena sosial, gerakan sosial, tumbuh dan berkembang begitu cepat seiring dengan terjadinya perubahan sosial.Disamping itu, secara sosiologi dan terencana dengan baik yang diorientasikan untuk mencapai suatu tujuan tertentu.

(C) 2019 Hasanuddin Journal of Sociology. All rights reserved.

\section{PENDAHULUAN}

Dengan berlangsungnya perubahan sosial yang begitu cepat dan kemudian bergerak secara simultan dengan makin kompleks serta lengkapnya kebutuhan masyarakat, maka hal ini berdampak pada munculnya beragam kelompok yang memiliki latar belakang serta tujuan yang berbeda.Kondisi seperti

\footnotetext{
* Corresponding author. Tel.: 081242995418

E-mail address: aharis2000@yahoo.com
} 
ini semakin terasa dalam beberapa dekade terakhir ini terutama sejak terjadinya beragam konflik serta pertikaian baik pada tingkat kelompok dan organisasi maupun konflik yang terjadi antar Negara yang ternyata hal tersebut berdampak besar bagi lahirnya aneka rupa gerakan sosial dan perilaku kolektif lainnya.

Oleh karena itu, dapat dikatakan bahwa kelihatannya semakin maju, heterogen dan modern suatu masyarakat maka semakin terbuka ruang yang lebih bebas bagi terbentuknya gerakan sosial. Selain itu, gerakan sosial pun muncul karena berbagai faktor, kita sebut saja misalnya gerakan yang dilakukan oleh sekelompok buruh dengan tujuan untuk meningkatkan taraf hidup dan kesejahteraan dikalangan kaum pekerja dengan cara mengubah kebijakan pemerintah yang tentu saja kebijakan itu lebih memperhatikan nasib kaum buruh serta pekerja lainnya.

Demikian juga halnnya dengan gerakan sosial yang dilakukan oleh sejumlah organisasi mahasiswa yang menolak berbagai bentuk peraturan dan kebijakan yang dibuat oleh penguasa serta para wakil rakyat yang dinilainya akan membebani kehidupan rakyat terutama bagi mereka yang berada pada strata bawah. Begitu pula dengan gerakan sosial yang dilakukan dikalangan kaum pecinta lingkungan hidup yang mana mereka ini sering kali terlibat dalam banyak kasus aksi unjuk rasa, mogok kerja, demonstrasi serta aksi protes terhadap kegiatan yang dipandangnya mengganggu keseimbangan ekosistem dan merusak kelestarian lingkungan. Dengan kata lain, karena begitu beragamnya tuntutan, keinginan harapan dan kebutuhan rakyat sehingga wajar apabila gerakan sosial ini pun memiliki tipe dan tujuan yang berbeda satu sama lain.

Walaupun begitu, perlu juga dipahami jika gerakan sosial ini meski ada yang sifatnya melembaga dan melakukan kegiatan secara regular namun adapula jenis gerakan sosial yang kegiatannya hanya dilakukan dalam kasus tertentu karena mereka yang terlibat didalamnya berpartisipasi secara aktif pada saat dihadapkan pada kegiatan tertentu yang memiliki implikasi luas bagi masyarakat.Sebenarnya jika dilihat dari sejarahnya akar historis yang cukup panjang khususnya kalau kita melihat munculnya gerakan yang dilakukan oleh sejumlah orang dengan tujuan untuk membentuk suatu lingkungan baru yang dipandangnya tentram dan damai.Adapun gerakan sosial model ini dapat diamati dari munculnya gerakan sosial yang dikategorikan sebagai gerakan separatis yang dimaksudkan untuk membentuk suatu Negara baru yang terjadi diberbagai belahan dunia.

Oleh sebab itu, penting untuk dicatat bahwa rupanya tipe gerakan sosial begitu beragam jenisnya sehingga dengan demikian wajar manakala dampak yang ditimbulkannya pun memiliki corak yang berwarna berbeda dan ini sangat tergantung pada faktor pemicu berakhirnya suatu gerakan sosial. 


\section{BAHAN DAN METODE}

Dalam membahas tentang gerakan sosial dalam perspektif sosiologi maka metedologi penelitian yang digunakan yaitu sifatnya kualitatif dengan cara melakukan pengumpulan data melalui studi pustaka yang bersumber dari berbagai referensi seperti Buku, Jurnal, Surat Kabar , Majalah dan pemanfaatan internet melalui komputer sehingga berbagai data dan informasi diperoleh yang berkaitan dengan gerakan sosial.

\section{PEMBAHASAN}

\subsection{Memahami Gerakan Sosial}

Dalam referensi sosiologis dikenal adanya berbagai pendapat yang dikemukakan oleh para sosiolog yang terkait dengan pengertian tentang apa sesungguhnya yang dimaksud dengan istilah gerakan sosial. Cohen misalnya (1983) menjelaskan bahwa yang dimaksud dengan istilah gerakan sosial yaitu gerakan yang dilakukan oleh sejumlah orang yang sifatnya terorganisir dengan tujuan untuk merubah atau mempertahankan sesuatu unsur tertentu dalam masyarakat yang luas. Lalu, lebih jauh Cohen mengemukakan tentang adanya beberapa ciri suatu gerakan sosial yang diantaranya : adanya tujuan yang ingin dicapai (sasaran), terencana serta terdapat suatu ideologi.

Sementara itu Zurcher dan Snow dalam buku Michener dan Delamater (1999) merumuskan definisi gerakan sosial sebagai kegiatan yang sifatnya kolektif yang mengekspresikan tingkat kepedulian yang tinggi tentang beberapa isu tertentu. Selanjutnya, Touch dalam kuppuswamy (1979) mengemukakan bahwa yang dimaksud dengan gerakan sosial yaitu suatu usaha sejumlah individu yang secara kolektif bertujuan untuk menyelesaikan masalah yang muncul dalam suatu masyarakat. Adapun Blumer dan Allen (1980) menganggap gerakan sosial merupakan sebuah kegiatan kolektif untuk memunculkan kehidupan baru.

Kemudian,Gusfield dan Allen (1980) menganggap apabila suatu gerakan sosial sebagai kegiatan dan kepercayaan masyarakat akan harapan adanya perubahan beberapa aspek dari kondisi sosial. Dari berbagai definisi tentang gerakan sosial sebagaimana yang dijelaskan sebelumnya menunjukkan bahwa sesungguhnya yang dimaksud dengan gerakan sosial yaitu suatu gerakan yang dilakukan sejumlah orang yang sifatnya terencana dan terorganisir dengan tujuan untuk mencapai suatu tujuan tertentu sesuai dengan misi gerakan itu.Disamping itu, jika dilihat dari cirinya maka sebuah gerakan sosial memiliki beberapa ciri tersendiri.

Kita sebut saja umpamanya pendapat yang dikemukakan oleh David Aberle yang mana dia 
menggunakan kriteria perubahan yang dikehendaki baik itu pada tingkat individu maupun pada level masyarakat serta besarnya perubahan yang diinginkan. Lalu, Locer 2002 menjelaskan bahwa suatu gerakan sosial setidaknya memiliki tiga ciri khas antara lain : pertama, terorganisir. Dalam hal ini, perilaku yang ditampilkan para pendukung gerakan sosial berpedoman pada cara tertentu yang diorganisir oleh seorang pemimpin itu melalui adanya tugas yang dilimpahkan pada anggotanya. Kedua, membutuhkan jangka waktu yang cukup lama.Maksudnya sebuah gerakan sosial dapat bertahan dalam rentang waktu yang relatif lama sesuai dengan tujuan gerakan sosial itu.

Dan ketiga sengaja dibentuk. Maksudnya keberadaan suatu gerakan sosial memang sengaja dibentuk oleh anggotanya dan setiap anggota gerakan itu akan memainkan peran sesuai dengan tugas masingmasing. Walaupun gerakan sosial dibedakan dengan konsep perilaku kolektif dalam kajian sosiologi yang mana konsep yang terakhir ini lebih bersifat spontan dan berlangsung dalam waktu relatif singkat namun menurut pendapat Smelser bahwa suatu perilaku kolektif paling tidak memiliki beberapa macam ciri seperti : pertama kondisi struktural dalam arti struktur masyarakat sedemikian rupa yang memberi ruang lebih terbuka dan longgar bagi munculnya perilaku kolektif. Kedua adanya tekanan struktural yang maksudnya fenomena nasional ini muncul manakala individu dalam masyarakat dihadapkan pada satu masalah yang sangat penting dan kemudian mereka secara bersama mencari solusi untuk mengatasi masalah tersebut.

Ketiga terdapatnya keyakinan umum (Generalized Beliefs) hal ini muncul ketika timbul keyakinan bersama dikalangan warga masyarakat akan sesuatu yang menjadi sumber masalah lalu dicarikan solusi penyelesaiannya. Keempat, faktor pemicu (pendorong). Suatu gerakan akan muncul kepermukaan manakala sebelumnya didahului oleh beragam faktor pemicu. Terlebih lagi kalau muncul rumor (isu) yang berisi informasi yang dinilai amat berlebihan sehingga dapat membangkitkan emosi masyarakat.Kelima aksi mobilisasi.Biasanya perilaku kolektif muncul karena tampilnya seorang tokoh (pemimpin) yang dianggap mampu merumuskan berbagai kepentingan dan keinginan masyarakat untuk melakukan suatu kegiatan baik itu berupa perilaku kolektif maupun gerakan sosial.

Tentu saja peran pemimpin ini menjadi sangat penting karena dia mampu mengakomodasi, mengorganisir dan mengartikulasi berbagai keinginan, harapan serta kepentingan publik yang bersifat patent selama ini. Patut pula dipahami jika sesungguhnya banyak kepentingan dan keinginan ingin disampaikan oleh publik terutama bagi mereka yang berada pada lapisan soisal bawah masyarakat.Hanya saja, keinginan tersebut seringkali tidak mencuat kepermukaan karena kurangnya orang bersedia tampil sebagai pemimpin sekaligus berperan dalam merumuskan serta membuat strategi yang dipandang ideal, tepat dan baik bagi warga masyarakat. Itulah sebabnya, begitu besarnya peran 
yang harus dilakukan seorang pemimpin khususnya publik untuk melakukan suatu gerakan sosial sehingga wajar apabila pemimpin ini memiliki peran yang sangat sentral bagi munculnya perilaku kolektif serta gerakan sosial yang biasanya ditampilkan dalam bentuk aksi unjuk rasa, demonstrasi, mogok dan beragam bentuk kegiatan lainnya yang ditujukan untuk merubah atau bisa saja mendukung kebijakan yang dibuat pemerintah.

Dan keenam operation of social control. Ketika berlangsung suatu kegiatan yang dikelompokkan dalam tipe perilaku kolektif maka untuk menciptakan suasana yang kondusif, tertib dan terkendali tentu diperlukan hadirnya sejumlah elemen masyarakat seperti aparat penegak hukum, pejabat pemerintahan, tokoh masyarakat serta media yang mana kesemua komponen ini dinilai memberi kontribusi penting bagi ketertiban dan ketentraman masyarakat. Apalagi, muncul ketegangan dan konflik antara masyarakat (rakyat) dengan Negara (pemerintah) maka mau tak mau salah satu solusi yang dianggap penting untuk menciptakan suasana kondusif bagi masyarakat yaitu diperlukan hadirnya suatu lembaga yang sifatnya independen, otonom serta memiliki legitimasi yang kuat untuk memediasi dan mengorbitrasi sebuah persoalan yang dampaknya bisa menimbulkan keresahan sosial.

Oleh sebab itu dengan melihat serta menganalisis sejumlah pendapat yang dikemukakan oleh sosiolog yang relevan dengan ciri gerakan sosial maka secara umum dapat disimpulkan bahwa suatu gerakan sosial memiliki sejumlah karakteristrik yang meliputi : pertama, terdiri dari sejumlah orang. Dalam hal ini, gerakan sosial hanya bisa dibentuk kalau didukung oleh sejumlah orang yang memilikik persepsi, motif dan sikap yang sama terhadap suatu masalah.Kedua, mempunyai tujuan tertentu.Artinya suatu gerakan sosial yang muncul dan berkembang ditengah masyarakat tentu memiliki misi, sasaran dan target tertentu yang ingin dicapai. Contohnya gerakan sosial yang dilakukan dikalangan kaum buruh, petani, nelayan dan aneka rupa profesi lainnya yang mana masing-masing gerakan sosial tersebut memiliki tujuan dan kepentingan yang berbeda satu sama lainnya sesuai dengan tipe dan corak gerakan sosial itu.

Ketiga bersifat terorganisir. Penting untuk diketahui kalau suatu gerakan sosial dapat bertahan dalam waktu yang cukup lama karena gerakan itu dibentuk tidak bersifat spontanitas melainkan melalui proses yang cukup panjang, terencana, terorganisir dan mempunyai aturan baik yang sifatnya tertulis maupun tidak yang patut diikuti oleh anggota oraganisasi tersebut. Terlebih lagi, dengan semakin rumitnya kepentingan publik yang harus diakomodasi maka konsekuensinya kemudian mereka yang terlibat dalam gerakan sosial tersebut harus mampu menyusun suatu konsep, rencana dan program yang bersifat sistematis serta terukur sehingga sasaran kegiatan yang menjadi agenda program gerakan sosial itu dapat tercapai. Yang keempat didukung dana yang cukup. Suatu gerakan sosial hanya dapat bekerja secara efisien dan efektif manakala didukung dana yang memadai untuk membiayai seluruh aktivitas 
yang telah dirancang sedemikian rupa dalam program kegiatan gerakan sosial itu.

Karena itu, tidak mengherankan apabila dalam berbagai kasus tertentu mereka yang menjadi partisipan aktif suatu gerakan sosial harus terlibat dalam kegiatan pencarian dana yang mana ini dimaksudkan agar supaya seluruh rencana yang telah disusun sedemikian rupa dapat diimplementasikan sesuai dengan misi dan tujuan organisasi. Dan akhirnya memiliki momen yang tepat.Suatu gerakan sosial hanya bisa dilakukan sesuai dengan tujuan yang diinginkan kalaum mereka yang terlibat didalamnya memperhitungkan faktor situasi, kondisi dan waktu yang dinilai tepat untuk melakukan aktivitas mereka.Alasannya gerakan sosial yang dilakukan dalam situasi yang tidak tepat tidak hanya berpotensi menimbulkan kerugian waktu, pikiran dan tenaga tetapi juga hal ini berakibat pada semakin besarnya biaya yang harus dikeluarkan untuk sesuatu yang dipandang tidak memberikan manfaat khususnya bagi masyarakat.

Umpamanya saja mereka yang pro pada kepentingan rakyat miskin lalu melakukan aksi unjuk rasa disaat harga komoditas untuk kebutuhan sehari-hari masih berada dalam situasi dan kondisi yang normal. Demikian juga halnya misalnya dengan kaum buruh yang melakukan aksi protes terhadap para pengusaha guna mendukung kenaikan upah disatu sisi, tetapi disisi lain justru para pekerja sudah menerima gaji sesuai dengan kesepakan kaum buruh dengan pengusaha dan pada saat yang sama harga kebutuhan pokok pun tetap dalam kondisi normal dan bahkan beberapa diantaranya malah mengalami penurunan.Oleh sebab itu, untuk memulai gerakan sosial maka berbagai faktor harus diperhitungkan termasuk didalamnya dampak sosial ekonomi gerakan sosial tersebut.

\subsection{Tipe Gerakan Sosial}

Sebagai salah satu gejala sosial yang kerapkali muncul ditengah masyarakat dengan tujuan untuk mencapai suatu tujuan tertentu dan dilakukan oleh sekelompok orang secara terorganisir maka apabila dilihat dari perspektif sosiologi tentu gerakan sosial ini dapat dibagi kedalam beberapa macam. Contohnya menurut Cohen (1983) yang membagi jenis gerakan sosial tersebut kedalam beberapa tipe yaitu: Pertama, gerakan ekspresif. Dalam masyarakat yang sudah maju dan modern individu acapkali ingin mengungkapkan (mengekspresikan) berbagai keinginannya untuk mendapat perhatian dan simpati publik. Misalnya saja, gerakan yang dilakukan dikalangan kaum remaja dan pemuda dalam bentuk menciptakan model/gaya baru baik itu berupa cara berpakaian maupun penampilan yang dianggap unik orang lain. Bahkan dalam kategori gerakan ini dapat pula dimasukkan aliran musik misalnya "Break Dance" dikalangan kaum remaja di Amerika awal tahun 1980 an yang mana aliran musik seperti ini sengaja diekspresikan dikalangan penciptanya sebagai bentuk ungkapan perasaan 
mereka.

Kedua, gerakan regresif. Adapun tipe gerakan sosial ini sengaja dilakukan oleh sekelompok orang dengan tujuan untuk mengembalikan apa yang ada sekarang ini ke keadaan sebelumnya. Dengan kata lain mereka yang melakukan gerakan sosial regresif merasa kecewa serta frustasi melihat keadaan sosial sekarang ini.Contohnya gerakan yang dilakukan dikalangan kelompok $\mathrm{Ku}$ Klux Klan yang menginginkan agar supaya hak sipil dan kebebasan kaum orang kulit hitam (Black American) ditempatkan pada status sosial yang lebih rendah. Ketiga gerakan progresif. Bagi mereka yang terlibat dalam gerakan ini pada dasarnya bertujuan untuk meningkatkan taraf hidup serta kesejahteraan kelompok tertentu dalam masyarakat misalnya saja gerakan sosial yang dilakukan dikalangan serikat pekerja dalam bentuk unjuk rasa dan protes menuntut kenaikan upah baik kaum buruh serta pekerja lainnya.

Keempat gerakan reformis.Sedangkan tipe gerakan sosial ini lebih diorientasikan pada terciptanya perubahan dan pembaruan aspek tertentu dalam masyarakat. Contoh di Bulan Mei 1998 para mahasiswa dari berbagai universitas di Indonesia melakukan gerakan sosial dan menuntut diadakannya pembaharuan dan perubahan khususnya yang terkait dengan praktek kolusi, korupsi dan nepotisme. Begitu juga halnya yang terjadi di Uni Soviet di tahun 1980 an yang waktu itu masyarakat menuntut dilakukannya pembaharuan dan perubahan yang dampaknya berakibat runtuhnya Uni Soviet dan kemudian terpecah kedalam beberapa Negara merdeka, otonom dan berdaulat.

Kelima gerakan revolusioner. Tidak seperti halnya gerakan reformasi, yang hanya menuntut dilakukannya perubahan terhadap aspek tertentu dalam masyarakat maka dalam gerakan sosial yang sifatnya revolusioner ini justru menuntut lebih jauh hingga dilakukan perubahan bersifat total dan radikal terhadap seluruh aspek kehidupan manusia dan tatanan sosial yang ada. Menurut Sztompka (2004) menjelaskan bahwa revolusi berbeda dengan bentuk perubahan sosial lainnya yakni (a) menimbulkan perubahan dalam cakupan terluas yang menyentuh semua tingkat dan dimensi masyarakat: ekonomi, politik, kultur, organisasi sosial, kehidupan sehari-hari dan kepribadian manusia.

(b) Dalam bidang tersebut, perubahannya radikal, fundamental, menyentuh inti bangunan dan fungsi sosial. (c) perubahan yang terjadi sangat cepat, tiba-tiba, seperti ledakan dinamit ditengah aliran lambat proses historis. (d) dengan semua alasan itu, revolusi adalah pertunjukan perubahan paling menonjol, waktunya luar biasa cepat dan karena itu sangat mudah diingat. Keenam gerakan utopian.Dalam konteks gerakan sosial ini yang mana dilakukan oleh sekelompok orang dengan tujuan untuk membentuk suatu lingkungan yang dianggap ideal dan baik bagi mereka. Salah satu contoh termasuk dalam gerakan sosial bersifat utopian yaitu gerakan yang dilakukan dikalangan kaum separatis yang ingin membentuk suatu Negara baru dengan cara memisahkan diri dari suatu Negara. 
Dalam banyak kasus, gerakan kelompok separatis dapat ditemui disejumlah Negara diseluruh dunia.Meskipun begitu, harus dipahami kalau gerakan sosial seperti ini muncul sebagai manisfestasi dari perasaan kecewa, frustasi serta ketidakpuasaan sekelompok orang terhadap kaum penguasa yang dinilainya berlaku tidak adil, diskriminasi, eksploitasif dan tidak transparan sehingga dianggap bersikap otoriter pada kelompok tertentu dalam masyarakat. Dengan kata lain, apa yang dilakukan dikalangan kaum separatis tak lain mereka berjuang keras untuk mendirikan suatu Negara baru yang dianggapnya ideal dan mampu menciptakan kedamaian serta meningkatkan taraf hidup dan kesejahteraan mereka. Dalam realitasnya, ternyata terdapat beberapa Negara baru yang dibentuk sebagai dampak yang ditimbulkan dari tipe gerakan separatis yang masih dalam proses perjuangan separatis yang masih dalam rentan waktu yang terbilang lama.

Dan ketujuh, gerakan migrasi. Pada dasarnya mereka yang terlibat dalam gerakan ini merasa tidak begitu puas dengan kondisi kehidupan sosial ekonomi mereka sekarang sehingga mereka memutuskan untuk berpindah kesuatu wilayah yang lain dengan harapan dapat memperoleh kehidupan sosial ekonomi yang jauh lebih baik dibandingkan dengan keadaan sebelumnya. Disamping itu, sudah barang tentu ada faktor pendorong yang menyebabkan mereka meninggalkan daerah asalnya misalnya : sempitnya lapangan kerja, rendahnya gaji mereka terima, kurangnya fasilitas pendidikan dan kesehatan, minimnya sarana hiburan serta sejumlah faktor lainnya yang mendorong seseorang untuk meninggalkan kampung halamannya.

Lalu, disisi lain ada faktor penarik yang dapat membangkitkan keinginan, minat serta harapan seseorang yang berasal dari daerah tujuan umpamanya tersedianya lapangan kerja dengan upah yang relatif tinggi, terdapatnya sarana pendidikan, kesehatan dan hiburan yang cukup, serta aneka bentuk faktor penarik lainnya yang mana semua ini memiliki pengaruh yang sangat besar untuk menarik seseorang meninggalkan tempat tinggal sebelumnya.

Disamping itu, tidak seperti halnya dengan Cohen maka Locer (2002) membagi gerakan sosial paling tidak kedalam empat jenis antara lain: pertama, Alternative Social Movement. Untuk tipe gerakan sosial ini dimaksudkan hanya ingin merubah pemikiran dan perilaku individu tertentu dengan menggunakan cara tertentu pula. Contohnya gerakan sosial yang dilakukan oleh kelompok GRANAT yang ingin mengampanyekan anti narkoba agar supaya kaum remaja menjauhi penggunaan barang haram tersebut karena dampaknya sangat buruk bagi masa depan generasi muda. Kedua, Redemptive Social Movements.Yaitu suatu gerakan sosial yang dilakukan dengan tujuan merubah perilaku kelompok tertentu dalam masyarakat dengan ruang lingkup yang terbatas.Misalnya gerakan yang dilakukan dikalangan sekte tertentu yang sasarannya ingin merubah persepsi dan perilaku anggotanya. 
Ketiga, Reformative Movement. Pada prinsipnya target yang ingin dicapai gerakan sosial ini lebih diorientasikan pada perubahan aspek tertentu dalam masyarakat. Umpamanya gerakan People Power yang tujuannya ingin merubah sistem politik dan pemerintahan yang selama ini dinilainya otoriter, dan sarat dengan transaksi yang bersifat kolutif dan koruptif suatu bentuk pemerintahan yang demokratis, beradab serta mengapresiasi prinsip kesetaraan.Dan keempat, Revolutionary Social Movement. Berbeda halnya dengan tiga tipe gerakan sosial diatas maka dalam jenis gerakan sosial revolusioner lebih diorientasikan pada terjadinya suatu perubahan secara total dan menyeluruh pada semua aspek kehidupan masyarakat termasuk didalamnya ideologi suatu Negara.

Selanjutnya gerakan sosial jika dilihat dari proses terbentuknya maka ada beberapa tahap yang harus dilalui diantaranya : Pertama, Incipient Stage. Ketika muncul kegelisahan diantara individu maka lambat laun mereka yang mengalami keresahan ini saling berbagi informasi dengan melalui komunikasi yang sifatnya efektif.Terlebih lagi, disaat yang bersamaan muncul pula pemimpin dan para agitator lainnya yang mampu mengakomodasi serta mengartikulasi kepentingan publik.

Kedua, Organizational Stage. Untuk tahap ini, peran seorang pemimpin semakin diperkuat kemudian seluruh agenda rencana kegiatan yang mencakup didalamnya rencana aksi yang dilakukan telah disusun sedemikian rupa secara terorganisir dan sistematis sehingga apa yang dilakukan dilapangan sudah merupakan bagian dari rencana yang dibuat sebelumnya. Dan akhirnya, Institutinal Stage. Sedangkan untuk tahap yang berikutnya sebagai puncak dari rangkaian tahapan gerakan sosial memasuki fase kelembagaan dalam arti setelah melihat membaca situasi gerakan sosial tersebut mendapat dukungan luas dari publik maka gerakan sosial ini akan dilembagakan dalam bentuk organisasi yang formal dan diharapkan keberadaannya mampu bertahan dalam jangka waktu yang lama.

\section{PENUTUP}

Berdasarkan hasil penelitian pustaka yang dilakukan menunjukkan bahwa rupanya suatu gerakan sosial dapat didefinisikan sebagai gerakan yang dilakukan sejumlah orang dengan tujuan untuk menciptakan perubahan atau mungkin ingin mempertahankan sesuatu unsur yang dinilai sudah mapan dikalangan individu dalam masyarakat.Selain itu, munculnya gerakan sosial ini pada dasarnya didorong oleh adanya ketidakpastian yang diresahkan sekelompok orang terhdap berbagai aspek kehidupan manusia selama ini dengan melalui serangkaian tahap misalnya mulai dari tahap kegelisahan, kegusaran, formalisasi hingga tahap kelembagaan.

Dalam kaitannya dengan jenis gerakan sosial maka pada umumnya tipe gerakan ini dapat dibagi kedalam kategori, umpamanya gerakan sosial yang bersifat regresif, progresif, reformis, alternative, revolusioner, redemif, otopian dan gerakan sosial imigrasi. Oleh karena itu, begitu bervariasinya tipe 
gerakan sosial ini sehingga secara sosiologi dapat dijelaskan kalau cepat lambatnya muncul gerakan itu dapat dipengaruhi pada kuat tidaknya frekuensi intensitas interaksi sosial diantaranya individu dan membangun gerakan itu yang selanjutnya berdampak luas bagi pencapaian target, tujuan dan sasaran sesuai dengan misi masing-masing jenis gerakan sosial.

\section{REFERENCES}

Allen. D.E. 1980. Social Psyhology as Social Process. Wadworth Inc : California.

Basir. 2004. Perilaku Demonstran Ditinjau dari Pola Asuh Orang Tua. Yogyakarta : Pasca Sarjana UGM.

Brannen. 2004. Memadu Metode Penelitian Kualitatif dan Kuantitatif. Yogyakarta : Pustaka Pelajar Off Set.

Buechler M,Steven.2000. Social Movements.Oxford: Oxford University Press.

Cohe. J Bruce. 1983. Sosiologi suatu pengantar. Jakarta : PT Bina Aksara.

Happer. 1993. Gerakan Massa. Jakarta : Yayasan Obor Indonesia.

Kuppuswamy, B. 1979. Elements of Social Psychology. New Delhi : Vikas Publishing Hous PVT Ltd. Locer. 2002. Collective Behavior. New Jersey : Pearson Education Inc. Upper Sadle River.

Matulessy, Andik. 2005. Mahasiswa dan Gerakan Sosial. Surabaya-RT. Dieta Persada.

Michener. 1999. Social Psychology. Fortworth : Harcourt Brace College Publ.

Oberchall,Anthony.1995.Social Movements.New Jersey: The Transaction Publishers.

Situmorang Wahib Abdul. 2013. Gerakan Sosial. Yogyakarta : Pustaka Pelajar.

Sztompka Piots. 2004. Sosiologi Perubahan Sosial. Jakarta : Prenada Media. 